\title{
Acquisition of azide-resistance by elevated SecA ATPase activity confers azide-resistance upon cell growth and protein translocation in Bacillus subtilis
}

\author{
Akitaka Nakane, ${ }^{1}$ Hiromu Takamatsu, ${ }^{1}$ Akihiro Oguro, ${ }^{1}$ Yoshito Sadaie, ${ }^{2}$ \\ Kouji Nakamura' and Kunio Yamane ${ }^{1}$
}

Author for correspondence: Kunio Yamane. Tel: +8129853 6680. Fax: +81298536680.

\footnotetext{
1 Institute of Biological Sciences, University of Tsukuba, Tsukuba-shi, Ibaraki 305, Japan

2 National Institute of Genetics, Mishima-shi, Shizuoka 411, Japan
}

\begin{abstract}
We isolated four azide-resistant secA mutants of Bacillus subtilis and found that all of them were the result of a single amino acid replacement of threonine 128 of SecA by alanine or isoleucine. In the presence of $1.5 \mathrm{mM}$ sodium azide, cell growth and protein translocation of the wild-type strain were completely inhibited, but those of the azide-resistant mutant strains were not. Wild-type and two mutant SecA proteins were purified. Both the basal level and the elevated ATPase activity of the mutant SecA proteins were threefold higher than those of the wild-type SecA. The elevated ATPase activity of the SecA mutants was reduced upon the addition of $1.5 \mathrm{mM}$ sodium azide by only $5-10 \%$ as compared with $40 \%$ for that of the wild-type. These results indicate that the elevated ATPase activity of the SecA mutants is resistant to sodium azide and that it is also required for the protein translocation process of $B$. subtilis.
\end{abstract}

Keywords: Bacillus subtilis, $\operatorname{Sec} A$, azide resistance, $\sec A$ mutant, ATPase activity

\section{INTRODUCTION}

The Gram-positive bacterium Bacillus subtilis has a strong ability to secrete extracellular enzymes into the culture medium, but little is known about its protein translocation machinery in comparison with Escherichia coli. Recently, B. subtilis genes which code for proteins homologous to E. coli SecA (Sadaie et al., 1991; Overhoff et al., 1991), SecY (Nakamura et al., 1990; Suh et al., 1990) and SecE (Jeong et al., 1993) have been identified, suggesting similarities between the protein translocation machinery of E. coli and B. subtilis.

The B. subtilis SecA protein, which consists of 841 amino acid residues, has $50 \%$ sequence identity with the $E$. coli SecA protein and, like E. coli SecA, has an ATPase activity (Takamatsu et al., 1992). E. coli SecA is a peripheral membrane protein which plays a crucial role as a translocase in protein translocation (Oliver et al., 1990a; Wickner et al., 1991) interacting with SecY and SecE (Brundage et al., 1990; Hendrick \& Wickner, 1991). It interacts with the signal peptide and the mature part of the protein to be secreted (Cunningham \& Wickner, 1989; Lill et al., 1990), and its ATPase activity is elevated in the presence of a precursor protein, SecY/E, and phospho- lipids, under which conditions it is called 'translocation ATPase' (Lill et al., 1989). SecA couples ATP hydrolysis and protein translocation, and the translocation ATPase activity is known to be necessary for protein translocation in E. coli (Mizushima et al., 1991). Recently, van der Wolk et al. (1993) and Klose et al. (1993) have reported that lysine 106 of B. subtilis SecA is important for SecA ATPase activity through their studies using mutant SecA proteins. However the role of ATPase activity in $B$. subtilis SecA is still unclear.

Sodium azide is known to inhibit the translocation ATPase activity of SecA protein and protein translocation in E. coli (Oliver et al., 1990b). Knott \& Robinson (1994) recently reported that sodium azide inhibited protein translocation across the chloroplast thylakoid membrane. Therefore, sodium azide is thought to be an inhibitor of the Sec-dependent protein translocation pathway. It does not inhibit free-state SecA and has no effect on the basal level SecA ATPase activity. In E. coli, mutations that confer azide-resistance are located at various positions in the $\sec A$ gene (Oliver et al., 1990b; Fortin et al., 1990), and in $B$. subtilis, a gene which confers azide-resistance is known to be located near the $\sec A$ gene on the genetic map (Henner \& Hoch, 1982). Meens et al. (1993) have 
Table 1. Bacterial strains and plasmids

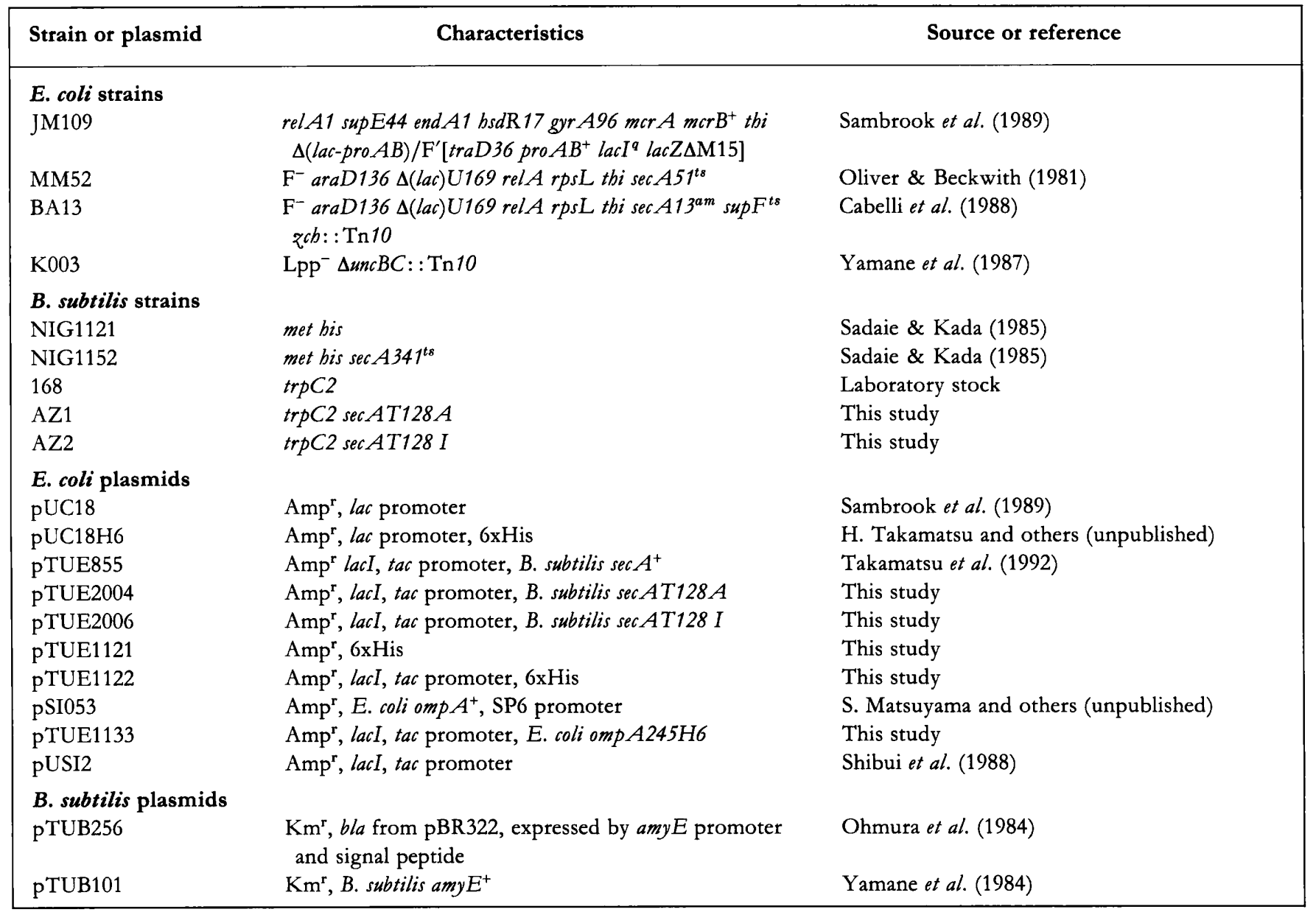

recently shown that translocation of OmpA in B. subtilis is also inhibited by sodium azide, as in E. coli, and suggested that it is carried out by a protein translocation machinery similar to that of E. coli which consists of SecA, SecE and SecY.

In this study we examined the effect of sodium azide on the ATPase activity of SecA in the protein translocation system of $B$. subtilis. We isolated and analysed four azideresistant $\sec A$ mutants of $B$. subtilis. All of the mutants have one amino acid replacement at threonine 128 of SecA, and their elevated ATPase activities were resistant to sodium azide.

\section{METHODS}

Bacterial strains and plasmids. The bacterial strains and plasmids used in this study are listed in Table 1.

Mutagenesis of $B$. subtilis. The azide-resistant mutants of $B$. subtilis were isolated by the procedure of Adelberg et al. (1965). B. subtilis NIG1121 strain (wild-type) was cultured in penassay broth at $37^{\circ} \mathrm{C}$ and treated with $N$-methyl- $N^{\prime}$-nitro- $N$ nitrosoguanidine (NTG) at $50 \mu \mathrm{g} \mathrm{ml}^{-1}$ at $37^{\circ} \mathrm{C}$ for $1 \mathrm{~h} ; 10^{10}$ cells were then spread onto $100 \mathrm{~L}$-agar plates $\left(10^{8}\right.$ cells on each plate) and incubated at $37^{\circ} \mathrm{C}$ overnight.

Synthetic oligonucleotides and PCR procedures. Three over- lapping DNA regions [A: -75 to $+882 ; \mathrm{B}:+734$ to +1644 ; C: +1558 to +2582 (Sadaie et al., 1991)] of the B. subtilis $\sec A$ gene of the azide-resistant mutants were prepared by PCR (Sambrook et al., 1989) using the appropriate chromosomal DNA as the templates and the six DNA primers as follows: BSA-1, 5'-AGAGGTATACATGGACTAGT-3'; BSA-2, 5' TAAGGCCTGGTTGATATGGT-3'; BSA-3, 5' -AAGCGGAGAAGGATTACACG-3'; BSA-4, 5'-TCTGCGCATCAA'TTCATCT'T-3'; BSA-5, 5'-AATCAGCTTCGAGGTCGTTC-3'; and BSA-6, 5'-CTCAT'TAAAAGATCGCAGCC-3'. These oligonucleotides were purchased from Sawady Technology (Tokyo, Japan). The reaction mixtures contained $660 \mathrm{ng}$ of each forward and reverse primer, $1 \mu \mathrm{g}$ genomic DNA, and 2.5 U Taq polymerase (Promega) in a final volume of $100 \mu \mathrm{l}$. Amplification proceeded as follows: $2 \mathrm{~min}$ at $94^{\circ} \mathrm{C}$, then $1 \mathrm{~min}$ at $55^{\circ} \mathrm{C}$ and $2 \mathrm{~min}$ at $72{ }^{\circ} \mathrm{C}$ for 50 cycles. The amplified products (A, $957 \mathrm{bp}$; B, $911 \mathrm{bp}$; C, $1025 \mathrm{bp}$ ) were purified by agarose gel electrophoresis.

DNA sequencing. DNA sequencing was performed by the dideoxy chain-termination method of Sanger et al. (Sambrook et al., 1989). The double-stranded pUC18 plasmid DNAs, in which PCR products were inserted, were used as templates for the Taq Dye-Deoxy Terminator Cycle Sequencing Kit (Applied Biosystems). The same oligonucleotides used for the PCR reaction were used as specific primers for the sequence reaction. Readout of DNA sequence was performed with an automatic DNA sequencer (Applied Biosystems, model 373A). 


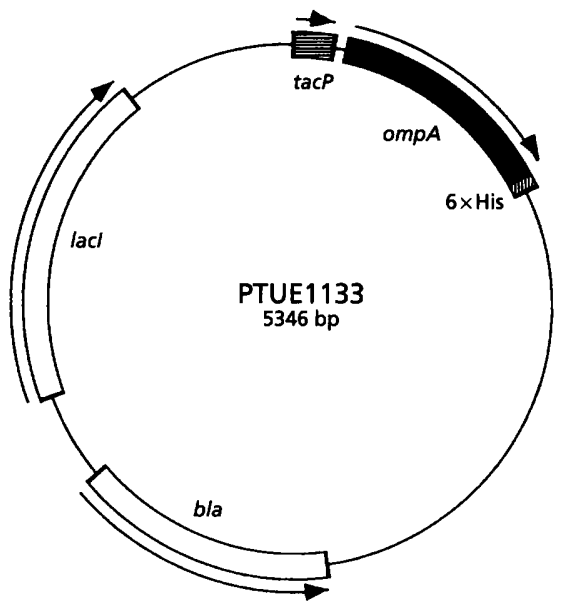

Fig. 1. Structure of plasmid pTUE1133.

Construction of plasmids. To express the $\sec A$ genes of $B$. subtilis azide-resistant mutant strains in E. coli under the control of the tac promoter, ClaI-HpaI $0.5 \mathrm{kbp}$ DNA fragments containing azide-resistant mutations were prepared from the PCR products of two azide-resistant strains (Azi-1 and Azi-14) and inserted into the ClaI-HpaI site of plasmid pTUE855. The constructed plasmids were designated as pTUE2004 $(\sec A T 128 A)$ or pTUE2006 $(\sec A T 128 I)(7.9 \mathrm{kbp})$.

Plasmid pUC18H6 was digested by EcoRI, treated with T4 DNA polymerase, and then digested by $S_{s p} \mathrm{I}$. The resulting $0.7 \mathrm{kbp}$ DNA fragment was inserted into the PvuII site of plasmid pUC18 to obtain plasmid pTUE1121 (3.1 kbp). Plasmid pTUE1121 was digested by EcoRI, treated with T4 DNA polymerase, and then digested by ScaI. The resulting $0.8 \mathrm{kbp}$ DNA fragment was religated with the Bam HI (treated with T4 DNA polymerase)-ScaI fragment of plasmid pUSI2. The constructed plasmid was designated as pTUE1122 (4.5 kbp).

To express the E. coli omp $A$ gene under the control of the tac promoter in $E$. coli, the PvuII-SspI $0.8 \mathrm{kbp}$ DNA fragment containing the truncated $o m p A$ gene from plasmid pSI053 was inserted into the $S m a I$ site of plasmid pTUE1122. The constructed plasmid was designated as pTUE1133 $(5.3 \mathrm{kbp})$. Plasmid p TUE1133 contains the $\beta$-lactamase and lacI genes, and the $\operatorname{smp} A$ gene which expresses under the control of the tac promoter (Fig. 1). The OmpA protein produced has six histidine residues in its carboxyl terminal and it was purified using affinity binding with Ni-NTA resin (QIAgen).

Radiolabelling, immunoprecipitation and electrophoresis of $\alpha$-amylase and $\boldsymbol{\beta}$-lactamase. Processing of the signal peptide of $\beta$-lactamase and $\alpha$-amylase in the transformants of the wild-type (B. subtilis 168) and azide-resistant strains (AZ1 and AZ2) carrying plasmids pTUB101 or pTUB256 was analysed by pulse-chase. Cells were grown at $37^{\circ} \mathrm{C}$ in $\mathrm{M} 9$ medium containing $0.4 \%(\mathrm{v} / \mathrm{v})$ glycerol and 18 amino acids $\left(20 \mu \mathrm{g} \mathrm{ml}^{-1}\right)$ excluding methionine and cysteine, in the presence of $10 \mu \mathrm{g}$ kanamycin $\mathrm{ml}^{-1}$. After $3 \mathrm{~h}\left(\mathrm{OD}_{660}\right.$ approx. 0.20$), 1.5 \mathrm{mM}$ sodium azide was added. After appropriate periods, the cells were pulse-labelled with $20 \mu \mathrm{Ci}\left[{ }^{35}\right.$ S $]$ methionine $\mathrm{ml}^{-1}(740 \mathrm{kBq}$ $\mathrm{ml}^{-1}$ ) (NEN Research Products) for $1 \mathrm{~min}$ and chased with $200 \mu \mathrm{g}$ unlabelled methionine $\mathrm{ml}^{-1}$. The cells were withdrawn at periods of $0,1,2$ and $4 \mathrm{~min}$. They were incubated with $10 \mathrm{mg}$ egg-white lysozyme $\mathrm{ml}^{-1}$ at $37^{\circ} \mathrm{C}$ for $10 \mathrm{~min}$, boiled for $3 \mathrm{~min}$ in the presence of $0 \cdot 1 \%$ SDS, and used for immunoprecipitation with the antiserum against $\alpha$-amylase or $\beta$-lactamase. The precipitates were then separated by SDS-PAGE and autoradiograms were obtained. The intensity of the bands for precursor and mature proteins in the autoradiograms were quantified using a densitometer (Bio Image, Millipore), and the processing rates of $\alpha$-amylase and $\beta$-lactamase were calculated.

Purification of B. subtilis wild-type and azide-resistant SecA proteins from $E$. coli transformants. B. subtilis SecA proteins of azide-resistant and wild-type strains were expressed and purified from E. coli MM52 transformants carrying plasmid pTUE855, pTUE2004 or pTUE2006, under the conditions described previously (Takamatsu et al., 1992). The purity of the SecA proteins exceeded $90 \%$, based upon SDS-PAGE followed by staining with Coomassie Brilliant Blue (data not shown).

Purification of proOmpA connecting with six histidine residues on Ni-NTA resin. An E. coli BA13 transformant carrying pTUE1133 was cultured in L-broth supplemented by $50 \mu \mathrm{g}$ ampicillin $\mathrm{ml}^{-1}$ at $30^{\circ} \mathrm{C}$ for $2 \mathrm{~h}$, and $2 \mathrm{mM}$ IPTG was added for a further $1 \mathrm{~h}$. The culture was then shifted to $42^{\circ} \mathrm{C}$ for $3 \mathrm{~h}$. The cells were harvested by centrifugation and suspended in sonication buffer $\left(50 \mathrm{mM} \mathrm{Na} \mathrm{HPO}_{4} / \mathrm{NaH}_{2} \mathrm{PO}_{4}, \quad \mathrm{pH} 7 \cdot 8\right.$; $300 \mathrm{mM} \mathrm{NaCl}$ ). Cells were disrupted by sonic oscillation $(20 \mathrm{Kc}$, $4 \mathrm{~min}$ ) using a Kubota Isonator Model 200M (Kubota Medical Appliance Supply, Tokyo) in iced water, and the disrupted cells were collected by centrifugation at $10000 \mathrm{~g}$ for $20 \mathrm{~min}$ at $4{ }^{\circ} \mathrm{C}$. The pellet was suspended in buffer $\mathrm{B}$ ( $8 \mathrm{M}$ urea, $0.1 \mathrm{M}$ $\mathrm{NaH}_{2} \mathrm{PO}_{4}, 0.01 \mathrm{M}$ Tris, $\mathrm{pH}$ adjusted to 8.0 with $\mathrm{NaOH}$ ), and the cell debris was removed by centrifugation at $20000 \mathrm{~g}$ for $10 \mathrm{~min}$. The supernatant was gently mixed with Ni-NTA resin (Qiagen) at $4{ }^{\circ} \mathrm{C}$ for $1 \mathrm{~h}$. The mixture was centrifuged and the pellet was washed three times with buffer $\mathrm{C}^{\prime}(50 \mathrm{mM}$ Tris $/ \mathrm{HCl}$, pH 6.5, $10 \mathrm{mM} \mathrm{NaCl}, 10 \mathrm{mM} \mathrm{KCl}, 5 \mathrm{mM} \mathrm{MgCl}_{2}, 8 \mathrm{M}$ urea). The pellets were then mixed with buffer $\mathrm{C}^{\prime}$ containing $200 \mathrm{mM}$ imidazole for $2 \mathrm{~min}$ at room temperature and centrifuged to obtain a supernatant containing the purified proOmpA protein having six histidine residues. The supernatant was used as the proOmpA preparation.

Assay of ATPase activity of SecA protein. Purified B. subtilis SecA $(1 \mu \mathrm{g})$ was dissolved in $100 \mu \mathrm{l}$ reaction buffer $[50 \mathrm{mM}$ Tris/ $\mathrm{HCl}, \quad \mathrm{pH} 7 \cdot 0, \quad 30 \mathrm{mM} \mathrm{KCl}, \quad 30 \mathrm{mM} \mathrm{NH}_{4} \mathrm{Cl}, \quad 5 \mathrm{mM}$ $\left(\mathrm{CH}_{3} \mathrm{COO}\right)_{2} \mathrm{Mg}, 1 \mathrm{mM}$ DTT] and reacted with $5 \mathrm{mM} \mathrm{ATP}$ at $37^{\circ} \mathrm{C}$ to evaluate the basal level ATPase activity.

Assays for the elevated ATPase activity were according to the method of van der Wolk et al. (1993). To remove membranebound $E$. coli SecA, inverted membrane vesicles prepared from E. coli strain K003 by the procedure of Yamada et al. (1989) were treated with $4 \mathrm{M}$ urea in TKMD buffer $[10 \mathrm{mM}$ Tris/acetate, $\mathrm{pH} 7 \cdot 0,50 \mathrm{mM} \mathrm{KCl}, 10 \mathrm{mM}\left(\mathrm{CH}_{3} \mathrm{COO}\right)_{2} \mathrm{Mg}, 1 \mathrm{mM}$ DTT] at $0{ }^{\circ} \mathrm{C}$ for $45 \mathrm{~min}$ and reprecipitated by centrifugation for $30 \mathrm{~min}$ at 90000 r.p.m. in a TLA -100.2 rotor at $4^{\circ} \mathrm{C}$. The resulting pellet was resuspended in a buffer $[50 \mathrm{mM}$ Tris $/ \mathrm{HCl}, \mathrm{pH} 7 \cdot 0$, $\left.30 \mathrm{mM} \mathrm{KCl}, 30 \mathrm{mM} \mathrm{NH}_{4} \mathrm{Cl}, 5 \mathrm{mM}\left(\mathrm{CH}_{3} \mathrm{COO}\right)_{2} \mathrm{Mg}\right]$ and used as urea-treated inverted membrane vesicles. The purified proOmpA ( $1 \mathrm{mg} \mathrm{ml}^{-1}$ in buffer $\mathrm{C}^{\prime}$ ) was diluted 50 -fold into reaction mixtures $(100 \mu \mathrm{l})$ containing the urea-treated inverted membrane vesicles $(15 \mu \mathrm{g}$ proteins in $100 \mu \mathrm{l})$, B. subtilis SecA protein $(1 \mu \mathrm{g})$, and $5 \mathrm{mM}$ ATP. This was incubated at $37^{\circ} \mathrm{C}$, arrested on ice, and the amount of released phosphate was measured as the elevated ATPase activity.

Measurements of released phosphate were performed as previously described (Takamatsu et al., 1992).

General DNA manipulations. DNA manipulation and E. coli transformation were accomplished by the methods outlined by Sambrook et al. (1989), and B. subtilis was transformed by the method of Wilson \& Bott (1968). 

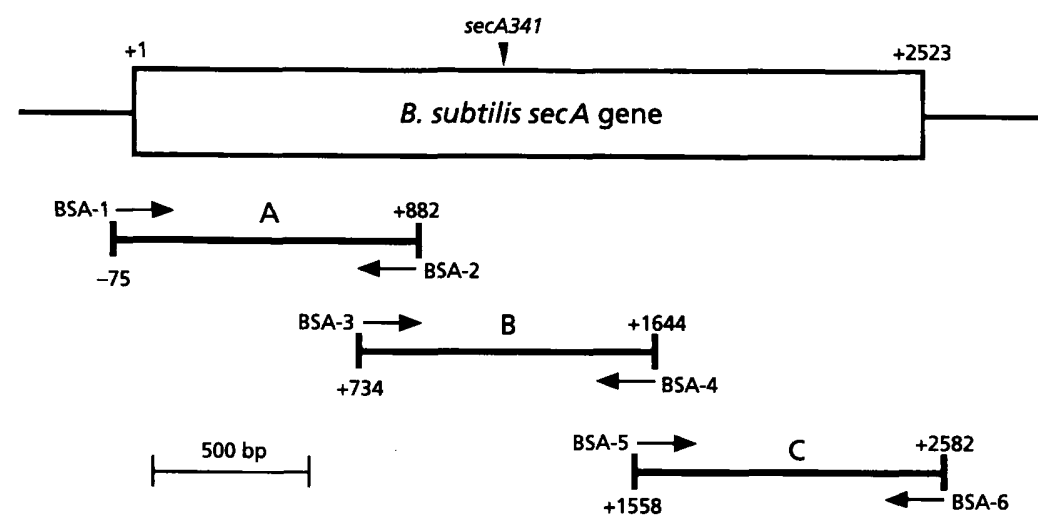

Fig. 2. Determination of the mutation site on sec $A$ responsible for azide-resistance. Three overlapping DNA regions (A: -75 to $+882 ; B:+734$ to $+1644 ; C:+1558$ to +2582 ) of the $B$. subtilis secA gene of azideresistant mutants were prepared by PCR using the appropriate chromosomal DNA as the templates and six DNA primers. Their location and direction on the $B$. subtilis secA gene are shown by arrows. The amplified products (A, $957 \mathrm{bp} ; \mathrm{B}, 911 \mathrm{bp}$; C, $1025 \mathrm{bp}$ ) were purified by agarose gel electrophoresis, and their ability to transform to an azide-resistant phenotype was tested using B. subtilis NIG1121 as the recipient. The arrow head $(\nabla)$ indicates the mutation site of $\sec A 341\left(\sec A^{t s}\right)$.

\section{RESULTS}

\section{Isolation of $B$. subtilis azide-resistant secA mutants}

To evaluate the sensitivity of $B$. subtilis to sodium azide, the wild-type strain NIG1121 was cultured at $37^{\circ} \mathrm{C}$ on L-

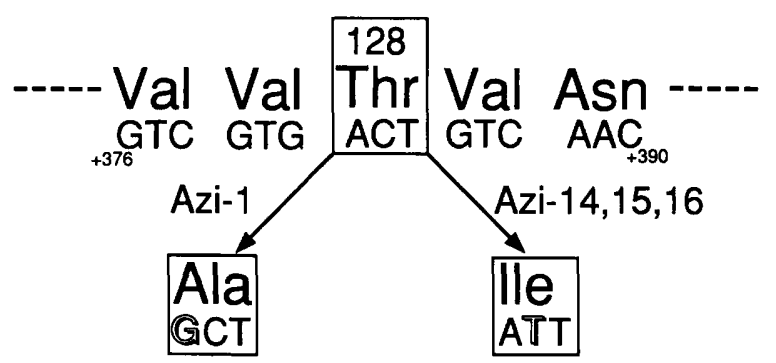

Fig. 3. Determination of the mutation sites in the secA gene that confer azide-resistance and the deduced amino acid replacement at the amino acid position threonine 128. Shadowed letters indicate the replaced nucleotides in azideresistant mutants. agar plates containing $0 \cdot 15,0 \cdot 3,0 \cdot 75,1 \cdot 5$, or $3 \mathrm{mM}$ sodium azide. This strain barely formed any colonies on the plate containing $0.75 \mathrm{mM}$ sodium azide, and no colonies were found when the concentration of the reagent was increased to $1.5 \mathrm{mM}$.

We then tried to isolate azide-resistant mutants of $B$. subtilis which have a mutation in the $\sec A$ gene. $B$. subtilis NIG1121 strain (wild-type $\sec A$ ) was treated with NTG and $10^{10}$ cells were then spread onto L-agar plates containing $1.5 \mathrm{mM}$ sodium azide and incubated at $37^{\circ} \mathrm{C}$ overnight. Twenty bacterial colonies were initially isolated as possible azide-resistant mutants and were designated as Azi-1 to Azi-20. They showed almost the same colony morphology on L-agar plates containing $1.5 \mathrm{mM}$ sodium azide compared with a wild-type colony in the absence of sodium azide. The chromosomal DNA of each mutant was extracted and introduced into the $B$. subtilis NIG1152 $\left(\sec A 341^{\mathrm{ts}}\right)$ strain which has a transition mutation resulting in an amino acid replacement from proline to leucine at residue $431 \mathrm{in} \mathrm{SecA}$ (Takamatsu et al., 1992). The transformants were spread onto L-agar plates
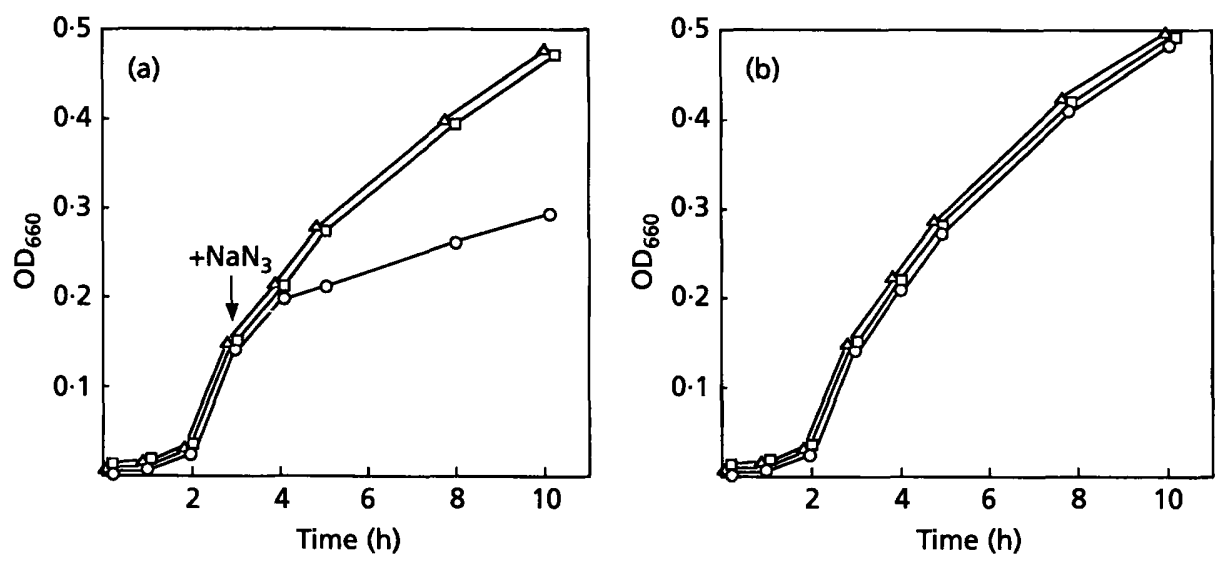

Fig. 4. Effect of sodium azide on cell growth of the wild-type and azide-resistant strains of B. subtilis. Strains AZ1 ( $\triangle$ ). AZ2 ( $\square$ ) and $168(O)$ were cultured in M9 medium at $37^{\circ} \mathrm{C}$. After $3 \mathrm{~h}$ cultivation, $1.5 \mathrm{mM}$ sodium azide was added (a), or not added (b). 


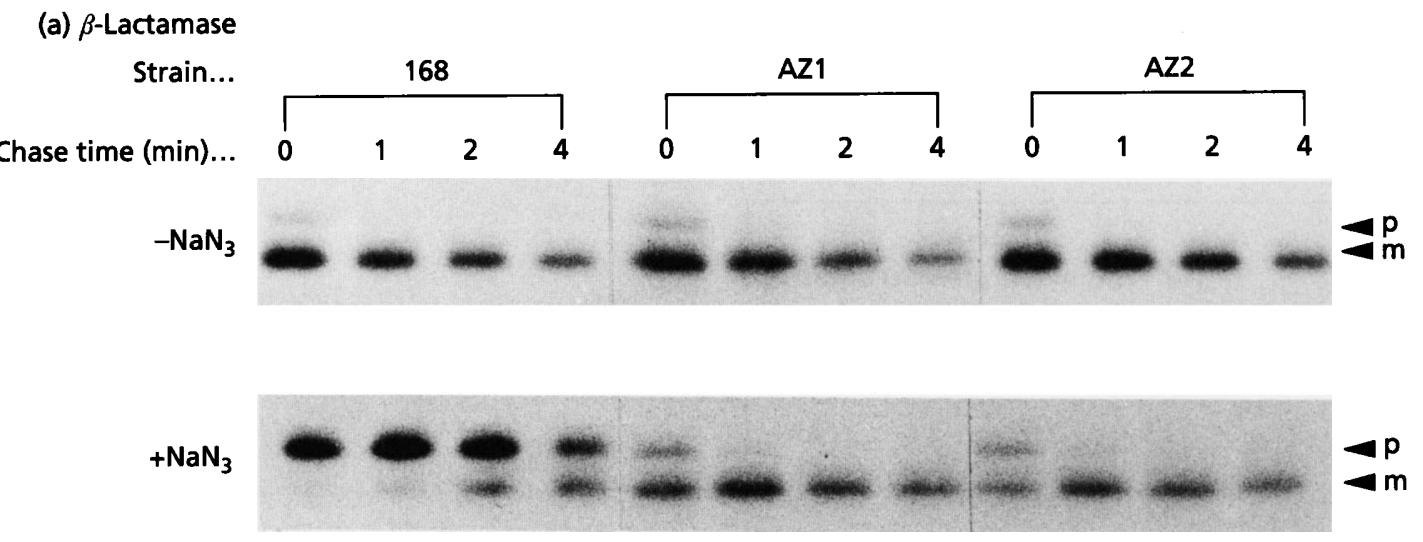

(b) $\alpha$-Amylase

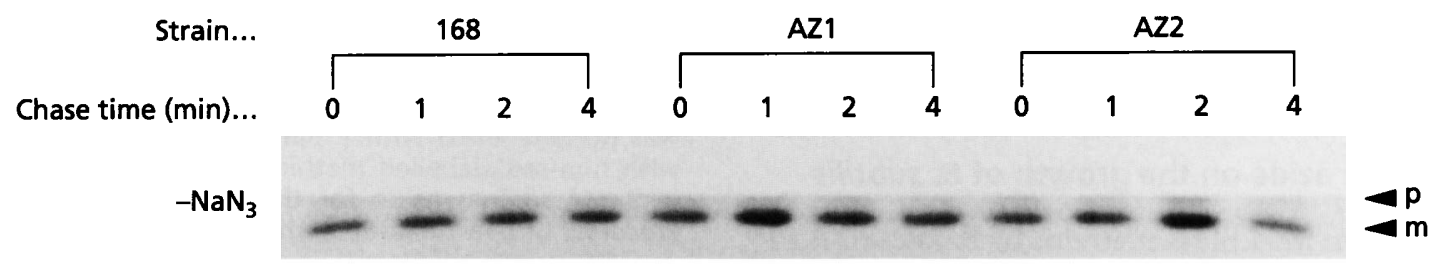

$+\mathrm{NaN}_{3}$

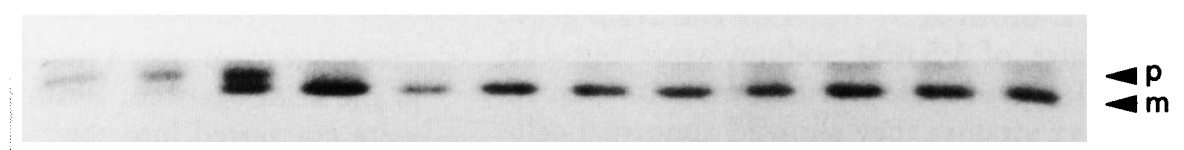

Fig. 5. Effect of sodium azide on the translocation of $\beta$-lactamase (a), and $\alpha$-amylase (b). B. subtilis strains 168, AZ1, and AZ2, harbouring plasmid pTUB256 or pTUB101, were cultured at $37^{\circ} \mathrm{C}$ in M9 medium. When cultures reached an $O D_{660}$ of $0.20,1.5 \mathrm{mM}$ sodium azide was added. After $30 \mathrm{~min}$, the cells were pulse-labelled with [ ${ }^{35} \mathrm{~S}$ ]methionine for $1 \mathrm{~min}$ and chased with non-radiolabelled methionine for 0 (lane 0), 1 (lane 1), 2 (lane 2), and 4 min (lane 4). Cells cultured in the presence or absence of sodium azide were immunoprecipitated with anti- $\beta$-lactamase or anti- $\alpha$-amylase antiserum, separated by electrophoresis on SDS-polyacrylamide gels, and visualized by autoradiography. $p$, Precursor of $\alpha$-amylase or $\beta$-lactamase; $\mathrm{m}$, mature form.

containing $1.5 \mathrm{mM}$ sodium azide and incubated at $42^{\circ} \mathrm{C}$. Azide-resistant mutants whose genomic DNA enabled the $\sec A 341^{\text {ts }}$ mutant strain to grow both at the nonpermissive temperature $\left(42^{\circ} \mathrm{C}\right)$ and on azide-containing plates were considered as possessing azide-resistance mutations at or near the $\sec A$ gene. Four of the twenty original mutant strains, Azi-1, Azi-14, Azi-15 and Azi-16, were thus selected as azide-resistant $\sec A$ mutants. The other 16 original mutants were not because their ability to transform to an azide-resistant phenotype was incomplete compared with that of the former strains.

\section{Determination of the mutational sites of azide- resistant mutants}

To determine the mutational sites in the four azideresistant mutants, three DNA fragments (A, B and $C$, shown in Fig. 2) of the $\sec A$ gene were prepared by PCR. Their chromosomal DNA was used as template and six synthetic DNA fragments were used as primers (Fig. 2).
The resulting 12 DNA fragments were separately introduced into wild-type $B$. subtilis strain NIG1121 and tested for the ability to transform the wild-type strain into an azide-resistant form on L-agar plates containing $1.5 \mathrm{mM}$ sodium azide. All the A fragments from the four azide-resistant strains had this transformation ability. They were then inserted into the SmaI site of the pUC18 vector and sequenced, revealing that azide-resistance was the result of single mutations in the $\sec A$ gene. The Azi1 strain had an $A$ to $G$ transition at nucleotide position +382 , corresponding to the replacement of threonine at amino acid position 128 of the SecA protein with alanine. Azi-14, Azi-15 and Azi-16 strains had a $C$ to $T$ transition at nucleotide position +383 , corresponding to the replacement of threonine 128 with isoleucine (Fig. 3). The other DNA fragments (B and C) from Azi-1 and Azi-14 mutant chromosomal DNA were also sequenced, but no mutation was found. B. subtilis 168 strain (wild-type $\sec A$ ) was transformed by the A fragments of Azi-1 and Azi-14, and the resulting transformants which have a single mutation in the $\sec A$ gene (in AZ1, threonine 128 of SecA 
Table 2. Basal level ATPase activity of SecA proteins

Aliquots containing $1 \mu \mathrm{g}$ each purified $\operatorname{Sec} A$ were incubated at $37^{\circ} \mathrm{C}$ in the presence of the indicated concentration of sodium azide.

\begin{tabular}{|c|c|c|c|c|}
\hline \multirow{2}{*}{$\begin{array}{l}\text { Protein } \\
\qquad \text { Azide concn (mM)... }\end{array}$} & \multicolumn{4}{|c|}{$\begin{array}{c}\text { Activity } \\
{\left[10^{2} \times \mathrm{pmol}(\mu \mathrm{g} \text { protein })^{-1} \mathrm{~min}^{-1}\right]}\end{array}$} \\
\hline & $\mathbf{0}$ & 1.5 & $7 \cdot 5$ & 15 \\
\hline Wild-type SecA & $2 \cdot 5$ & $2 \cdot 3$ & $2 \cdot 4$ & $2 \cdot 4$ \\
\hline AZ1 SecA & $6 \cdot 4$ & $6 \cdot 3$ & $6 \cdot 4$ & $6 \cdot 4$ \\
\hline$A Z 2 \operatorname{Sec} A$ & $5 \cdot 7$ & $5 \cdot 7$ & $5 \cdot 7$ & $5 \cdot 8$ \\
\hline
\end{tabular}

was replaced by alanine; in $\mathrm{AZ2}$, by isoleucine) were selected and used for further studies.

\section{Effect of sodium azide on the growth of B. subtilis}

The azide-resistant $\sec A$ mutant strains of $B$. subtilis, AZ1 and $A Z 2$, formed colonies on L-agar plates in the presence of $1.5 \mathrm{mM}$ sodium azide but the wild-type strain, 168, did not. Similarly, in L-broth at $37^{\circ} \mathrm{C}, \mathrm{AZ1}$ and AZ2 grew well in the presence of $1.5 \mathrm{mM}$ sodium azide but 168 hardly grew at all. These azide-resistant mutants seemed to be cold-sensitive strains: they showed abnormal cellshape and poor growth at $23{ }^{\circ} \mathrm{C}$ in the absence of sodium azide (data not shown).

To examine the most suitable conditions for the pulsechase experiment, the growth of AZ1, AZ2 and 168 in M9 medium was measured. The wild-type and azide-resistant strains were cultured in L-broth at $37^{\circ} \mathrm{C}$ overnight by which time their cell densities had reached an $\mathrm{OD}_{660}$ of about $0 \cdot 85$. They were then inoculated into fresh $\mathrm{M} 9$ medium and cultured at $37^{\circ} \mathrm{C}$. After $3 \mathrm{~h}\left(\mathrm{OD}_{660}\right.$ about 0.20 ), $1.5 \mathrm{mM}$ sodium azide was added (Fig. 4a). Upon addition of sodium azide, growth of the wild-type strain began to slow after $1 \mathrm{~h}$, but that of the azide-resistant strains did not. In the absence of sodium azide, both the wild-type and azide-resistant strains grew well in M9 medium at about the same rate (Fig. 4b).

\section{Effect of sodium azide on protein translocation in $\boldsymbol{B}$. subtilis}

To study the effect of sodium azide on protein translocation in B. subtilis, the processing of the signal peptide of $\alpha$-amylase and $\beta$-lactamase was analysed by pulse-chase in the transformants of the wild-type (168) and azideresistant (AZ1 and $A Z 2$ ) strains carrying plasmid pTUB101 ( $\alpha$-amylase) or pTUB256 ( $\beta$-lactamase) (Fig. 5 ). In the absence of sodium azide, the precursor of both $\alpha$ amylase and $\beta$-lactamase was converted almost in its entirety into its mature form after $1 \mathrm{~min}$ chase in all cells. In the presence of $1.5 \mathrm{mM}$ sodium azide, more than $60 \%$ of $\beta$-lactamase and $20 \%$ of $\alpha$-amylase accumulated in their
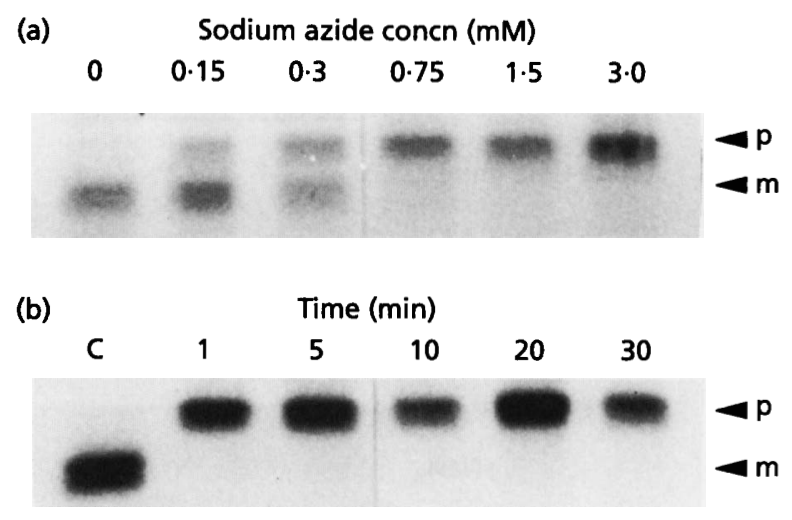

Fig. 6. Azide sensitivity of wild-type $B$. subtilis 168 . B. subtilis 168 carrying pTUB256 was grown in M9 medium at $37^{\circ} \mathrm{C}$ for $3 \mathrm{~h}$. (a) Ten minutes after the addition of the indicated concentrations of sodium azide, the cultures were pulselabelled with $\left[{ }^{35} \mathrm{~S}\right]$ methionine for $1 \mathrm{~min}$, chased with nonradiolabelled methionine for $1 \mathrm{~min}$, then analysed for the processing of $\beta$-lactamase by gel electrophoresis. (b) The culture was pulse-labelled with [ ${ }^{35} \mathrm{~S}$ ]methionine for $1 \mathrm{~min}$ and chased with non-radiolabelled methionine for $1 \mathrm{~min}$, after cultivation in $3 \mathrm{mM}$ sodium azide for the indicated lengths of time. $p$, Precursor of $\beta$-lactamase; $\mathrm{m}$, mature form; $C$, control.

precursor form after $4 \mathrm{~min}$ chase in the wild-type, whereas in the azide-resistant strains, most of the two precursors were converted into their mature form after only $1 \mathrm{~min}$ chase. Therefore, sodium azide inhibited the translocation of $\alpha$-amylase and $\beta$-lactamase in wild-type $B$. subtilis, but only slightly affected it in the azide-resistant $\sec A$ mutants.

To determine the concentration of sodium azide required to inhibit protein translocation in $B$. subtilis, $\beta$-lactamase processing was analysed by pulse-chase in the presence of various concentrations of sodium azide (Fig. 6a). In the presence of $0.15 \mathrm{mM}$ sodium azide, $30 \%$ of $\beta$-lactamase accumulated in the precursor form after $1 \mathrm{~min}$ chase. In the presence of $0.75 \mathrm{mM}$ sodium azide, protein translocation was completely inhibited.

In E. coli, sodium azide inhibits protein translocation rapidly (Oliver et al., 1990b). We studied how quickly sodium azide inhibited protein translocation in $B$. subtilis. Wild-type $B$. subtilis cultures were pulse-labelled after cultivation in the presence of $3 \mathrm{mM}$ sodium azide for various lengths of time, and processing of $\beta$-lactamase was analysed (Fig. 6b). Protein translocation in B. subtilis was inhibited completely within $1 \mathrm{~min}$ after addition of sodium azide. This result indicates that inhibition of protein translocation by sodium azide in $B$. subtilis is extremely rapid, as in E. coli.

\section{Effect of sodium azide on the ATPase activities of $B$. subtilis SecA protein}

Sodium azide is known to inhibit the translocation ATPase activity of $E$. coli SecA and block incorporation of proOmpA into the inverted membrane vesicles, but it 


\section{Table 3. Elevated ATPase activity of SecA proteins}

Aliquots containing $1 \mu \mathrm{g}$ each purified SecA, $2 \mu \mathrm{g}$ proOmpA and urea-treated inverted membrane vesicles were incubated at $37^{\circ} \mathrm{C}$ in the presence of the indicated concentration of sodium azide.

\begin{tabular}{|c|c|c|c|c|}
\hline \multirow{2}{*}{$\begin{array}{l}\text { Protein } \\
\qquad \text { Azide concn }(\mathrm{mM}) \ldots\end{array}$} & \multicolumn{4}{|c|}{$\begin{array}{c}\text { Activity } \\
{\left[10^{2} \times \mathrm{pmol}(\mu \mathrm{g} \text { protein })^{-1} \mathrm{~min}^{-1}\right]}\end{array}$} \\
\hline & $\mathbf{0}$ & 1.5 & $7 \cdot 5$ & 15 \\
\hline Wild-type SecA & $7 \cdot 6$ & $4 \cdot 6$ & $3 \cdot 8$ & $3 \cdot 4$ \\
\hline AZ1 SecA & $21 \cdot 0$ & $20 \cdot 0$ & $16 \cdot 4$ & $15 \cdot 8$ \\
\hline AZ2 SecA & $18 \cdot 6$ & $17 \cdot 7$ & $14 \cdot 9$ & $14 \cdot 5$ \\
\hline
\end{tabular}

does not affect the basal level SecA ATPase activity (Oliver et al., 1990b). Van der Wolk et al. (1993) have shown that $B$. subtilis SecA does not stimulate proOmpA incorporation into the inverted membrane vesicles of $E$. coli, but its ATPase activity is elevated in the presence of proOmpA and inverted membrane vesicles. We studied the effect of sodium azide on the basal level ATPase activity and the elevated ATPase activity of the purified wild-type and mutant SecA proteins of B. subtilis. Basal level ATPase activity of the SecA mutants was about two to three times higher than that of wild-type B. subtilis SecA (Table 2). The basal level ATPase activity of the wild-type and mutant SecA proteins of B. subtilis was not affected by $1.5-15 \mathrm{mM}$ sodium azide as is the case with the wild-type and azide-resistant SecA mutants of E. coli. The elevated ATPase activity of the SecA proteins was measured in the presence of proOmpA and urea-treated inverted membrane vesicles of $E$. coli (Table 3). The elevated ATPase activity of both mutant and wild-type SecA proteins increased almost threefold compared with the basal level ATPase activity. Inhibition of the elevated ATPase activities was then analysed: the elevated ATPase activity of the wild-type SecA in the presence of $1.5 \mathrm{mM}$ sodium azide showed only $50-60 \%$ of its azide-free activity; in contrast, the SecAs of the mutants were much less inhibited in the presence of $1.5 \mathrm{mM}$ sodium azide, retaining $90-95 \%$ of their elevated ATPase activity.

\section{DISCUSSION}

Sodium azide is an inhibitor of the Sec-dependent protein translocation pathway in E. coli. Oliver et al. $(1990 \mathrm{~b})$ and Fortin et al. (1990) analysed two different azide-resistant mutants, and found that the mutations were located in the sec $A$ gene: an $\mathrm{A}$ to $\mathrm{T}$ transversion at nucleotide position 1356, corresponding to the replacement of asparagine 179 with tyrosine; a $\mathrm{T}$ to $\mathrm{A}$ transversion at nucleotide position 2755 , corresponding to the replacement of leucine 645 with glutamine (Oliver et al., 1990b); a C to $\mathrm{T}$ transition at nucleotide position 2710 , corresponding to the re- placement of alanine 630 with valine; and a $\mathrm{C}$ to $\mathrm{T}$ transition at nucleotide position 2787 , corresponding to the replacement of arginine 656 with cysteine (Fortin et al., 1990). All of these amino acid replacement sites were located within the ATP binding cassettes (ABC) I or II of the E. coli SecA (Mitchell \& Oliver, 1993).

In this study, we isolated four azide-resistant $\sec A$ mutants of $B$. subtilis. Sodium azide inhibits not only SecA but also the enzymes related to the respiratory chain (Kobayashi \& Anraku, 1972). However, the single mutation occurring in the $\sec A$ gene conferred azide-resistance to $B$. subtilis, so the effect of $1.5 \mathrm{mM}$ sodium azide on the enzymes other than SecA was thought not to be critical. All of the mutants had only one amino acid replacement, occurring at threonine 128 (Fig. 3). In the case of E. coli, mutations which confer azide resistance occur at various positions in the $\sec A$ gene. Therefore, it may be possible to isolate other $B$. subtilis azide-resistant mutants in which SecA contains amino acid replacements other than at threonine 128 if we were to isolate more mutants by other procedures. However, this threonine residue is conserved among the SecA proteins of several species and is located in the ATP binding cassette I including the ATP binding motif A $\left({ }^{100}\right.$ MKTGEGKT $\left.{ }^{\mathbf{1 0 7}}\right)$ of B. subtilis SecA (Mitchell \& Oliver, 1993). Both the basal level and the elevated ATPase activities of azide-resistant SecA proteins were threefold higher than those of the wild-type SecA (Tables 2 and 3). Moreover, the amino acid replacement of threonine 128 of B. subtilis SecA by alanine to isoleucine resulted in azide resistance and a defect in growth at low temperature $\left(23^{\circ} \mathrm{C}\right)$. Therefore, this residue seems to have an important role in the proper function of SecA including its ATPase activity.

In this study, the processing of $\alpha$-amylase and $\beta$-lactamase was inhibited in wild-type $B$. subtilis in the presence of $1.5 \mathrm{mM}$ sodium azide. More than $20 \%$ and $60 \%$ of the pre- $\alpha$-amylase and pre- $\beta$-lactamase accumulated after 4 min chase in the wild-type cells, respectively (Fig. 5). Recently, Meens et al. (1993) showed that sodium azide inhibited the translocation of proOmpA in B. subtilis. In the presence of $0.15 \mathrm{mM}$ sodium azide, $30 \%$ of pre- $\beta$ lactamase accumulated after $1 \mathrm{~min}$ chase in B. subtilis (Fig. 6a). Compared with the fact that the presence of less than $1 \mathrm{mM}$ sodium azide does not inhibit protein translocation in E. coli (Oliver et al., 1990b), B. subtilis seems to be more sensitive to sodium azide. Furthermore, protein translocation of $B$. subtilis was completely inhibited within $1 \mathrm{~min}$ after the addition of $3.0 \mathrm{mM}$ sodium azide. This inhibition is extremely rapid comparable to that of E. coli (Fig. 6b). These facts indicate that sodium azide inhibits SecA-dependent protein translocation in $B$. subtilis very effectively.

In the azide-resistant $\sec A$ mutants, processing of $\alpha$ amylase and $\beta$-lactamase was marginally affected by sodium azide. The mutant cells grew normally and their protein translocation systems were not inhibited in the presence of $1.5 \mathrm{mM}$ sodium azide (Figs $4 \mathrm{a}$ and 5). The inhibition of protein translocation in $E$. coli by sodium azide is due to inhibition of the translocation ATPase 
activity of SecA protein (Oliver et al., 1990b). We examined the effect of sodium azide on the basal level and the elevated ATPase activities of purified B. subtilis SecA proteins. The basal level ATPase activity of both the wildtype and azide-resistant SecA proteins was not affected by sodium azide (Table 2). The elevated ATPase activity of wild-type B. subtilis SecA in the presence of proOmpA and inverted membrane vesicles was inhibited by sodium azide, as is that of wild-type E. coli SecA. In contrast, the elevated ATPase activity of the azide-resistant SecA mutants was less affected by sodium azide than that of the wild-type (Table 3). Therefore, the elevated ATPase activity of B. subtilis SecA, analogous to 'translocation ATPase' activity in E. coli, is thought to be inhibited by sodium azide and to have an important role in the protein translocation process. We propose that acquisition of azide resistance by the elevated ATPase activity confers azide resistance upon cell growth and protein translocation in B. subtilis.

\section{ACKNOWLEDGEMENTS}

We thank R. H. Doi (University of California at Davis) for providing the rabbit antiserum against $\beta$-lactamase, and $\mathrm{S}$. Matsuyama (University of Tokyo, Japan) for providing plasmid pSI053. We also thank Joel Smith for a critical reading of the manuscript. This work was supported in part by grants-in-aid for Scientific Research from the Ministry of Education, Science and Culture of Japan.

\section{REFERENCES}

Adelberg, E. A., Mandel, M. \& Chen, G. C. C. (1965). Optimal conditions for mutagenesis by $N$-methyl- $N^{\prime}$-nitro- $N$ nitrosoguanidine in Escherichia coli K-12. Biochem Biophys Res Commun 18, 788-795.

Brundage, L., Hendrick, J. P., Schiebel, E., Driessen, A. J. M. \& Wickner, W. (1990). The purified Eschericbia coli integral membrane protein SecY/E is sufficient for reconstitution of SecA-dependent precursor protein translocation. Cell 62, 649-657.

Cabelli, R. J., Chen, L., Tai, P. C. \& Oliver, D. B. (1988). SecA protein is required for secretory protein translocation into $E$. coli membrane vesicles. Cell 55, 683-692.

Cunningham, K. \& Wickner, W. (1989). Specific recognition of the leader region of precursor proteins is required for the activation of translocation ATPase of Escherichia coli. Proc Natl Acad Sci US A 86, 8630-8634.

Fortin, Y., Phoenix, P. \& Drapeau, G. R. (1990). Mutations conferring resistance to azide in Escherichia coli occur primarily in the $\sec A$ gene. $J$ Bacteriol 172, 6607-6610.

Hendrick, J. P. \& Wickner, W. (1991). SecA protein needs both acidic phospholipids and SecY/E protein for functional highaffinity binding to the Escherichia coli plasma membrane. $J$ Biol Chem 266, 24596-24600.

Henner, D. J. \& Hoch, J. A. (1982). In The Molecular Biology of the Bacilli, pp. 1-33. Edited by D. Dubnau. New York: Academic Press.

Jeong, S. M., Yoshikawa, H. \& Takahashi, H. (1993). Isolation and characterization of the secE homologue gene of Bacillus subtilis. Mol Microbiol 10, 133-142.

Klose, M., Schimz, K., van der Wolk, J., Driessen, A. J. M. \& Freudl, R. (1993). Lysine 106 of the putative catalytic ATPbinding site of the Bacillus subtilis SecA protein is required for functional complementation of Escherichia coli $\sec A$ mutants in vivo. $J$ Biol Chem 268, 4504-4510.

Knott, T. G. \& Robinson, C. (1994). The SecA inhibitor, azide, reversibly blocks the translocation of a subset of proteins across the chloroplast thylakoid membrane. $J$ Biol Chem 269, 7843-7846.

Kobayashi, H. \& Anraku, Y. (1972). Membrane-bound adenosine triphosphatase of Escherichia coli. J Biochem 71, 387-399.

Lill, R., Cunningham, K., Brundage, L. A., Ito, K., Oliver, D. B. \& Wickner, W. (1989). SecA protein hydrolyzes ATP and is an essential component of the protein translocation ATPase of Escherichia coli. EMBO J 8, 961-966.

Lill, R., Dowhan, W. \& Wickner, W. (1990). The ATPase activity of $\operatorname{Sec} A$ is regulated by acidic phospholipids, $\operatorname{Sec} Y$, and the leader and mature domains of precursor proteins. Cell 60, 271-280.

Meens, J., Frings, E., Klose, M. \& Freudl, R. (1993). An outer membrane protein (OmpA) of Escherichia coli can be translocated across the cytoplasmic membrane of Bacillus subtilis. Mol Microbiol 9 , 847-855.

Mitchell, C. \& Oliver, D. B. (1993). Two distinct ATP-binding domains are needed to promote protein export by Eschericbia coli SecA ATPase. Mol Microbiol 10, 483-497.

Mizushima, S., Tokuda, H. \& Matsuyama, S. (1991). In vitro biochemical studies on translocation of presecretory proteins across the cytoplasmic membrane of Escherichia coli. Methods Cell Biol 34, 107-146.

Nakamura, K., Takamatsu, H., Akiyama, Y., Ito, K. \& Yamane, K. (1990). Complementation of the protein transport defect of an Escherichia coli $\sec Y$ mutant (secY24) by Bacillus subtilis $\sec Y$ homologue. FEBS Lett 237, 75-78.

Ohmura, K., Nakamura, K., Yamazaki, H., Shiroza, T., Yamane, K., Jigami, H., Tanaka, H., Yoda, K., Yamazaki, M. \& Tamura, G. (1984). Length and structural effect of signal peptides derived from Bacillus subtilis $\alpha$-amylase on secretion of Escherichia coli $\beta$-lactamase in B. subtilis cells. Nucleic Acids Res 12, 5307-5319.

Oliver, D. B. \& Beckwith, J. (1981). E. coli mutant pleiotropically defective in the export of secreted proteins. Cell 25, 765-772.

Oliver, D. B., Cabelli, R. J. \& Jarosik, G. P. (1990a). SecA protein: autoregulated initiator of secretory precursor protein translocation across the E. coli plasma membrane. J Bioenerg Biomembr 22, 311-336.

Oliver, D. B., Cabelli, R. J., Dolan, K. M. \& Jarosik, G. P. (1990b). Azide-resistant mutants of Eschericbia coli alter the SecA protein, an azide-sensitive component of the protein export machinery. Proc Natl Acad Sci US A 87, 8227-8231.

Overhoff, B., Klein, M., Spies, M. \& Freudl, R. (1991). Identification of a gene fragment which codes for the 364 amino-terminal amino acid residues of a SecA homologue from Bacillus subtilis: further evidence for the conservation of the protein export apparatus in Gram-positive and Gram-negative bacteria. Mol \& Gen Genet 228, 417-423.

Sadaie, Y. \& Kada, T. (1985). Bacillus subtilis gene involved in cell division, sporulation and exoenzyme secretion. J Bacteriol 163, 648-653.

Sadaie, Y., Takamatsu, H., Nakamura, K. \& Yamane, K. (1991). Sequencing reveals similarity of the wild-type $d i v^{+}$gene of Bacillus subtilis to the Escherichia coli $\sec A$ gene. Gene 98, 101-105.

Sambrook, J., Fritsch, E. F. \& Maniatis, T. (1989). Molecular Cloning: 
a Laboratory Manual, 2nd edn. Cold Spring Harbor, NY: Cold Spring Harbor Laboratory.

Shibui, T., Uchida, M. \& Teranishi, Y. (1988). A new hybrid promoter and its expression vector in Escherichia coli. Agric Biol Chem 52, 983-988.

Suh, J. W., Boylan, S. A., Thomas, S. M., Dolan, K. M., Oliver, D. B. \& Price, C. W. (1990). Isolation of a $\sec Y$ homologue from Bacillus subtilis: evidence for a common protein export pathway in eubacteria. Mol Microbiol 4, 305-314.

Takamatsu, H., Fuma, S., Nakamura, K., Sadaie, Y., Shinkai, A., Matsuyama, S., Mizushima, S. \& Yamane, K. (1992). In vivo and in vitro characterization of the $\sec A$ gene product of Bacillus subtilis. $J$ Bacteriol 174, 4308-4316.

Wickner, W., Driessen, A. J. M. \& Hartl, F. U. (1991). The enzymology of protein translocation across the Escherichia coli plasma membrane. Annu Rev Biochem 60, 101-124.

Wilson, G. A. \& Bott, K. F. (1968). Nutritional factors influencing the development of competence in the Bacillus subtilis transformation system. $J$ Bacteriol 95, 1439-1449. van der Wolk, J., Klose, M., Breukink, E., Demel, R. A., de Kruijff, B., Freudl, R. \& Driessen, A. J. M. (1993). Characterization of a Bacillus subtilis SecA mutant protein deficient in translocation ATPase and release from the membrane. Mol Microbiol 8, 31-42.

Yamada, H., Tokuda, H. \& Mizushima, S. (1989). Proton motive force-dependent and -independent protein translocation revealed by an efficient in vitro assay system of Escherichia coli. J Biol Chem 264, 1723-1728.

Yamane, K., Hirata, Y., Furusato, Y., Yamazaki, H. \& Nakazawa, A. (1984). Changes in the properties and molecular weight of Bacillus subtilis $\mathrm{M}$-type and $\mathrm{N}$-type $\alpha$-amylase resulting from a spontaneous deletion. $J$ Biochem 94, 1849-1858.

Yamane, K., Ichihara, S. \& Mizushima, S. (1987). In vitro translocation of protein across Escherichia coli membrane vesicles requires both the proton motive force and ATP. J Biol Chem 262, 2358-2362.

Received 6 June 1994; revised 26 August 1994; accepted 6 September 1994. 